\title{
Knowledge and opinions of nurses about organ transplantation in a Polish hospital
}

\author{
Marta Makara-Studzińska', Agnieszka Kowalska', Artur Wdowiak², Karolina Kryś-Noszczyk ${ }^{1}$ \\ ${ }^{1}$ Independent Laboratory of Psychical Health, Medical University, Lublin, Poland \\ 2 Department of Obstetrics, Gynaecological Nursing and Obstetrics, Medical University, Lublin, Poland
}

Makara-Studzińska M, Kowalska A, Wdowiak A, Kryś-Noszczyk K. Knowledge and opinions of nurses about organ transplantation in a Polish hospital. J Pre-Clin Clin Res. 2013; 7(1): 48-52.

\begin{abstract}
:
Introduction: The term 'transplantation' is understood as an intervention involving transfer of cells, tissues or organs within one body or two bodies. The donor of any organ can be a living person (ex vivo transplant) or a dead person (ex mortuo transplant).

Objective: The aim of the study is to present the knowledge and opinions of nurses about organ donation for transplantation.

Materials and Method: The research tool used for the study was a survey which was carried out in 2010 among 100 randomlychosen nurses employed in the departments of surgery, orthopaedic surgery, gynaecology and anesthesiology of Independent Public Clinical Hospital No. 4 in Lublin (SPSK4).

Results: Although a considerable majority of nurses (73\%) support the idea of transplantation, the presented research, however, indicates insufficient knowledge of nurses on transplantation - which can influence their later possible decisions concerning the donation of organs for transplantation. Only $68 \%$ of the total number of respondents knew the meaning of term 'implied consent' in the context of organs transplantation from a cadaveric donor, and $72 \%$ of nurses did not know in what type of death the organs can be retrieved.

Conclusions: Nurses participating in the survey supported the idea of transplantation and would agree to donate their organs when necessary. Both the research presented in the paper and other research indicate the need for intensified education of medical personnel (particularly nursing staff) and students of medical subjects in the field of medical and legal aspects of transplantation of cells, tissues and organs.
\end{abstract}

\section{Key words}

transplantation, nurses, organ donor

\section{INTRODUCTION}

The concept of transplantation (from Latin 'transplantare' to graft, to transplant) means the transfer of cells (e.g. bone marrow) and tissues (e.g. skin) or organs (heart, kidney, liver) within a single organism, or between two organisms [1]. The donor of an organ may be a living donor (ex vivo procurement) or a deceased donor (ex mortuo procurement) [2].

The issue of transplantation and the terminology associated with transplantology as a branch of medicine has been widely discussed, both in the medical literature (Polish and foreign) on the subject, as well as in the Act of 1 July 2005 on the retrieval, storage and transplantation of cells, tissues and organs (Journal of Laws 2005, No. 169, item 1411) [3].

The process of material procurement to graft (from a deceased person) in the light of Polish law is acceptable, once irreversible cessation of brain function has been confirmed - so-called 'brain death'. Criteria and method of determining this condition are established by professionals in the relevant fields of medicine, appointed by the responsible Minister for Health, taking into account current medical knowledge (Article 9, items 1 and 2, of the Act of 1 July 2005 on the retrieval, storage and transplantation of cells, tissues and organs) [3]. Procurement of the cells, tissues or organs for transplantation is acceptable after confirmation

Address for correspondence: Marta Makara-Studzińska, Independent Laboratory of Psychical Health, Medical University, Chodzki 15, 20-092 Lublin, Poland E-mail:mmakara@go2.pl

Received: 16 November 2012; accepted: 19 June 2013 of death due to irreversible cardiac arrest (Article 9, Act on the procurement, storage and transplantation of cells, tissues and organs) [3].

Under Polish law, the procurement of cells, tissues or organs from cadaveric donors for transplantation can be carried out if the deceased person did not express objection during his/her lifetime (the so-called presumed consent) [3]. Objection can be expressed in one of three forms stipulated by Polish law:

1) the relevant entry in the central register of objections to the procurement of cells, tissues and organs from cadaveric donors;

2) a written statement with personal signature appended;

3) an oral statement made in the presence of at least two witnesses, confirmed in writing by the witnesses [3].

The objection may be withdrawn at any time, in the form of a written or oral statement made in the presence of at least two witnesses [4].

The issue of consent for the procurement of cells, tissues and organs is regulated variously in different countries. Mostly, however, one of two solutions is adopted: explicit consent of the donor expressed during lifetime, or so-called presumed consent. The first of these solutions (opting-in) is supported by such countries as the Netherlands, Sweden, the United Kingdom, Germany and the USA. Lack of explicit consent expressed during lifetime (in the legal systems requiring a prior declaration) will not exclude the opportunity of donating the organ. In Sweden, the procurement of an organ 
from a cadaver donor is possible if the fact that a person during his/her lifetime approved the idea of donation can be proved, and there are grounds for believing that such an operation would comply with a donor's beliefs. In the United Kingdom there is a system of examination as to whether the deceased (the potential donor) before death expressed any form of objection to a possible donation of organs after death for transplantation, or if such objection was reported by the spouse or a close relative $[4,5]$.

The principle of presumed consent (opting-out system), consisting in the lack of objection expressed by a potential donor during his/her lifetime or by the legal representative of a minor or a person not having capacity to act, or that person or a minor over the age of 16, is practiced in such countries as Poland, Austria, Belgium, Italy, France, Finland, Spain and Portugal $[4,5]$.

A review of the literature shows that throughout the world there is a deficit of organ donors. The shortage of donors post-mortem is a known problem in Germany. Willingness to donate in the general population is $80 \%$, but less than $14 \%$ have a donor card [6].

As a result of the German law on transplantation, every citizen will be regularly asked by the health insurance company about their relationship to the deceased organ donation - with no obligation to decide. The aim of the changes is to increase readiness for donations, as well as increasing the availability of organs. A study was conducted among 1,225 respondents to assess the level of knowledge of students at the University of Regensburg in Germany, and response to informed consent for post mortem organ transplantation. $31.5 \%$ of respondents had an organ donor card, $98 \%$ of respondents overall had a preference for organ donation [7].

There is considerable inequality in the number of living donor kidney transplants performed in patients of Central and Eastern European origin, and patients from Western Europe. In Western Europe, the number of living donor transplants is about three times higher. Recent studies have reported that the impact on the inequality is through a low level of knowledge about transplantation, and low willingness to communicate with people who needs transplantation [8].

In the past two decades in Greece, there has been remarkable progress in transplantation. However, organ donation remains controversial. A 2012 study reported that almost half of the respondents (48.3\%) wanted to be a donor, and $49.1 \%$ of the respondents expressed willingness to donate organs of their relatives, $55.7 \%$ of respondents were concerned about the procedure for the removal of organs, and $58.3 \%$ of the respondents may feel guilty after becoming a recipient of organ from relative. Women, and persons who are parents, often express their consent to organ donation. 63.7\% Orthodox Christians want to become donors [9].

In Romania, the shortage of donor organs is a major difficulty for the development of new life-saving surgical techniques because Romanians tend to be more reluctant to donation after death than most Europeans. Emotional and moral factors were most often cited by Romanian medical students as an excuse for indecision or refusal for organ donation for transplantation [10]. In Australia, in the light of recent scientific reports, a deficit of persons registering as an organ donor was also observed [11].

The effect of traditional oriental culture in China and Japan has resulted in the occurrence of lack of organ donation. The results of the study indicate that students' attitudes towards the Japanese deceased donation was more favourable than that of Chinese students (43.6\% versus $35.9 \%, \mathrm{p}=0.001)$. Several factors contributed to the positive response by the students in the two countries: the prospect of a close relative donation, and earlier blood donation [12].

A study from Israel reported that although transplantation treatments are effective and save the lives of so many people, only a few people are willing to donate organs. More than half of the study population in 2012 objected to organ donation or adoption. The most inhibiting factor in deciding on organ donation is the lack of information. Family relationships and the proximity of the donor to the recipient have a significant impact on the willingness to organ donation. Compensation for donor organs has little effect on the motivation to donate organs for life and after death [13].

In Nigeria, where there is a major problem in the transplantation of organs, the attitude of health workers, particularly doctors, is crucial to the success of organ donation. Of the 172 surveyed healthcare professionals, $59.3 \%$ of respondents reported willingness to donate organs. Doctors most often reported willingness to become donors. The most common reasons for the reluctance to donate organs is 'the fear of complications' (44.9\%) and 'lack of confidence in the health sector' (20.6\%) [14].

Objective: The aim of the study is to assess the knowledge and views of nurses about the donation of organs for transplants.

\section{MATERIALS AND METHOD}

The research tool used for the study was a survey consisting of two parts: the first part included questions concerning the knowledge of nurses about transplantology and personal attitude to the problems of transplantology, the second part of the questionnaire included questions about independent variables, such as: age, education, place of residence or marital status of the respondents.

Questions included in the survey were of closed and semi-closed character. The survey was carried out in July and August 2010 among 100 randomly-chosen nurses employed in the departments of surgery, orthopaedic surgery, gynaecology and anesthesiology at the Independent Public Clinical Hospital No. 4 in Lublin (SPSK4).

The study of relationships was made with the use of Pearson Chi square test. The significance level was confirmed by accepting the significance level $\mathrm{p}=0.05$. Statistical calculations were made with the use of Statistica 9.0 software.

In nurses' opinions on organ transplantation versus education, the level of significance was $\chi^{2}=16.07$. According to Table 3, the level of significance was $\chi^{2}=82.28$. In the part 'Do you know what is presumed consent?' with regard to wards the level of significance was $\chi^{2}=30.86$.

\section{RESULTS}

Among the studied respondents, the most numerous group were subjects aged $36-45$ years ( $47 \%$ of the total number of respondents participating in the research). The second most numerous age group were nurses aged $46-55$ years $(28 \%$ of the studied population). The smallest group included respondents aged up to 25 years (2\%). 
In terms of education level, the largest group included respondents with secondary education $-69 \%$ of the studied population. The second group of those surveyed comprised those with BA higher education - 21 subjects ( $21 \%$ of the studied population). Definitely the smallest group consisted of respondents with master higher degree $-10 \%$ of the surveyed population.

Most of respondents taking part in the survey (73\%) were confident or rather confident to donate their organs after death. Only $12 \%$ of the surveyed subjects objected donation and $15 \%$ hesitated about this problem (Tab. 1).

Table 1. Structure of the studied population in terms of consent to donate organs after death

\begin{tabular}{lcc}
\hline Consent to donate organs after death & N & \% \\
\hline Definitely yes & 34 & 34 \\
\hline Yes, but still hesitating & 39 & 39 \\
\hline Definitely no & 12 & 12 \\
\hline I haven't decided yet & 15 & 15 \\
\hline Total & $\mathbf{1 0 0}$ & $\mathbf{1 0 0}$ \\
\hline
\end{tabular}

Considering the opinions of the studied subjects on organ transplantation, it is worth noting that the great majority of nurses with higher education supported the idea of transplantation $-86 \%$ in the group of BA higher education, and $80 \%$ in the group of surveyed subjects with master degree. Only the respondents with secondary education were against organ donation (22\%) (Tab. 2). Statistical analysis confirmed that the calculated chi square is higher than theoretical, there is a relationship between nurse's education and the response to the above question. The relationship strength between the features expressed with correlation coefficient was 0.7 .

Table 2. Nurses' opinions on organ transplantation vs. education

\begin{tabular}{|c|c|c|c|c|c|c|c|}
\hline \multirow{2}{*}{$\frac{\text { Variable }}{\text { I am for }}$} & \multicolumn{2}{|c|}{ Secondary } & \multicolumn{2}{|c|}{ Higher (BA) } & \multicolumn{2}{|c|}{ Higher (Masters) } & \multirow{2}{*}{$\frac{N}{64}$} \\
\hline & 38 & $55 \%$ & 18 & $86 \%$ & 8 & $80 \%$ & \\
\hline I am against & 15 & $22 \%$ & 0 & - & 0 & - & 15 \\
\hline I have no opinion & 16 & $23 \%$ & 3 & $14 \%$ & 2 & $20 \%$ & 21 \\
\hline Total & & & & & & & 100 \\
\hline
\end{tabular}

In the surveyed group expressing willingness to donate their organs after death, $100 \%$ would also agree to donate their organs during their lifetime; only $44 \%$ would donate organs to close persons. In the studied group of 'hesitating' subjects, as much as $92 \%$ would agree to donate their organs during their lifetime to a close person, i.e. child (Tab. 3). Statistical analysis confirmed that the calculated chi square is higher than theoretical, there is therefore a relationship

Table 3. Willingness of nurses to donate their organs during lifetime with regard to given consent to donate their organs after death

\begin{tabular}{lrrrrrrrr}
\hline Variable & \multicolumn{1}{c}{ Yes } & \multicolumn{4}{c}{$\begin{array}{c}\text { Only to a close } \\
\text { person, i.e. child }\end{array}$} & No & N \\
\hline Definitely yes & 19 & $56 \%$ & 15 & $44 \%$ & 0 & - & 34 \\
\hline Yes, but still hesitating & 2 & $5 \%$ & 36 & $92 \%$ & 1 & $3 \%$ & 39 \\
\hline Definitely no & 1 & $8 \%$ & 3 & $25 \%$ & 8 & $67 \%$ & 12 \\
\hline I haven't decided yet & 0 & - & 14 & $93 \%$ & 1 & $7 \%$ & 15 \\
\hline Total & $\mathbf{2 2}$ & & $\mathbf{6 8}$ & & $\mathbf{1 0}$ & $\mathbf{1 0 0}$ \\
\hline
\end{tabular}

between nurse's education and the response to the above question. The relationship strength between the features expressed with correlation coefficient was 0.99 .

Only $68 \%$ of the total number of the respondents knew the meaning of the term 'presumed consent' in the context of organ transplantation from a cadaveric donor. The highest proportion of subjects who understood this statement was noted in the group of nurses employed in the anaesthesiology ward $-96 \%$, and in surgical ward $-88 \%$. The highest number of negative answers to the question in the survey was noted in the group of respondents from the gynaecology ward - 48\%, and orthopaedic ward (Tab. 4). Statistical analysis confirmed that the calculated chi square is higher than theoretical, there is therefore a relationship between nurse's education and response to the above question.

Table 4. "Do you know what is presumed consent?" with regard to wards

\begin{tabular}{lccccccc}
\hline Variable & \multicolumn{2}{l}{ Yes } & \multicolumn{2}{c}{ No } & $\begin{array}{c}\text { I have heard about } \\
\text { it for the first time }\end{array}$ & N \\
\hline Orthopaedic & 10 & $40 \%$ & 11 & $44 \%$ & 4 & $16 \%$ & 25 \\
\hline Surgery & 22 & $88 \%$ & 3 & $12 \%$ & 0 & - & 25 \\
\hline Gynaecology & 12 & $48 \%$ & 12 & $48 \%$ & 1 & $4 \%$ & 25 \\
\hline Anaesthesiology & 24 & $96 \%$ & 0 & - & 1 & $4 \%$ & 25 \\
\hline Total & $\mathbf{6 8}$ & & $\mathbf{2 6}$ & & $\mathbf{6}$ & $\mathbf{1 0 0}$ \\
\hline
\end{tabular}

\section{DISCUSSION}

Organ donation is a major component of transplant programmes; however, the rate of organ donation is relatively low. Understanding the attitudes and knowledge of people who have the ability to act as a donor will be necessary in the development of effective educational programmes that raise public awareness and commitment to organ donation.

In the Muslim world, religious leaders play an important role in shaping public opinion about organ transplantation. Research conducted in Turkey reported that religious people are of the opinion that donation is in line with Islamic beliefs, but only $51.5 \%$ of respondents indicated a willingness donate organs. $32.7 \%$ of respondents said they did not have enough knowledge about organ donation [15].

The Canadian health care system attempted to implement financial incentives for organ donors, which is a very controversial. The research concluded showed that the public perceived regulated financial incentives for donors as acceptable [16].

Public awareness of organ donation substantially affects organ transplantation programmes. The younger generation seems more open to the modern approach to transplantation, as reported by research from Tehran in Iran. This study was conducted to assess the attitudes and willingness of school children on organ donation. The study included 416 high school students in Tehran. The students had a very positive attitude towards donation: $63 \%$ of the students declared readiness to take organs from a deceased relative. The study showed that Iranian teenagers have a great attitude and a willingness to organ donation. Further studies on this issue are needed [17].

The results of the presented study confirmed that in the professional group of nurses a definite majority of respondents supported the idea of transplantation (73\%). Only $12 \%$ of the surveyed subjects objected to donation, and $15 \%$ hesitated 
about this problem. In the surveyed group ready to donate their organs after death, $100 \%$ would also agree to donate their organs during their lifetime, while only $44 \%$ would donate organs to close persons. In the studied group of 'hesitating' subjects, as much as $92 \%$ would agree to donate their organs during their lifetime to a close person, i.e. child.

According to research by other authors, $87.7 \%$ of nurses support transplantation, and $68.8 \%$ would consider donation of their organs if such a need arose [18]. The results presented by Molzahn have shown that transplantation of organs is supported by up to $92 \%$ of nurses [20], and research conducted by Squee et al showed that $78 \%$ of nurses have a positive attitude to the idea of donating organs [19]. Akgun et al state that physicians show a greater willingness to donate organs for transplantation than nurses [21]. Research conducted among Korean students of one of the higher schools of nursing showed that students support the idea of donating organs, and show willingness to become potential donors in the future [21].

At this point, it is worth raising the issue of the knowledge of medical personnel about the medical and legal aspects of organ donation. The presented research indicates, however, insufficient knowledge of nurses on transplantation - which can influence their later possible decisions concerning donation of organs for transplants. Only $68 \%$ of the total number of the respondents knew the meaning of the term 'presumed consent' in the context of organ transplantation from a cadaveric donor. Similar results have been obtained by other authors. Bener et al, state that many doctors (72.4\%) and nurses $(74.7 \%)$ do not know that brain death is the criterion for human death [23]. Importantly, $36 \%$ of medical students are not aware that brain death means death, not a coma [23]. Research conducted by Molzahn revealed fairly significant insufficiency of information concerning the donation of organs - only $71 \%$ of nurses responded correctly to questions assessing their level of knowledge in the field of transplantation [20]. Therefore, the lack of information is measurable and indicates the need for increased education.

A study was conducted the University of Hong Kong to determine the level of knowledge, attitudes, and evaluation involvement towards organ donation among nursing students. 362 students completed the questionnaire, 87 males and 257 females. 147 respondents (40.6\%) were registered as organ donors. The students responded correctly to 23.7 of 33 questions (71.8\%) in terms of knowledge about organ donation and transplantation. The year of study was strongly correlated with commitment to organ donation; therefore, providing promotional and educational materials to improve students' attitudes towards organ donation should begin in the first year of study [24].

According to research conducted by Bener et al., nurses (61.3\%) more likely than doctors (23.9\%) report a lack of sufficient knowledge about organ donation [23]. Moreover, according to some authors (Akgun et al), physicians have much better knowledge about the legal aspects of organ donation than nurses, and the lack of comprehensive information definitely has a negative impact on the attitude of the public (including health professional) to the idea of transplantation [21].

Research in Germany has also shown a significant deficit in the level of knowledge about the transplantation after brain death, $52.7 \%$ of respondents were unaware of the need for intensive care. The responsible authorities should fill in the gaps in knowledge in order to achieve 'informed' consent for organ donation, which can improve the availability and the number of donors [7].

Adequate knowledge and an appropriate level of education is a significant factor influencing the positive attitude and willingness to donate organs for grafting [18].

\section{CONCLUSIONS}

1. Nursing staff participating in the survey support the idea of transplantation, and may be willing to donate their own organs in the event of such a need.

2. Research conducted in various parts of the world confirms the positive effect, i.e. a widespread acceptance of organ donation by the representatives of health professionals.

3. There is a need for intensified education of medical personnel (particularly nursing staff) and students of medical subjects in the area of the medical and legal aspects of the transplantation of cells, tissues and organs.

\section{REFERENCES}

1.http://encyklopedia.pwn.pl (access: 14.10.2008).

2.Zajdel J. Prawo medyczne dla kardiologów [Medical Law for cardiologists]. Łódź: Wydawnictwo Progress, 2009 p. 67-68 (in Polish).

3. Ustawa z dnia 1 lipca 2005 r. o pobieraniu, przechowywaniu i przeszczepianiu komórek, tkanek i narządów (Dz. U. 2005 Nr 169 poz. 1411). [The Act of 1 July 2005 on the collection, storage and transplantation of cells, tissues and organs] (in Polish).

4. Nesterowicz M. Prawo medyczne [Medical Law]. Toruń: Wydawnictwo „Dom Organizatora”, 2007 p. 291-301 (in Polish).

5.Zielińska E. Transplantacja w świetle prawa w Polsce i na świecie [Transplantation of the law in Poland and around the world]. Państ Prawo. 199; 6: 23-25.

6. Heits N, Guenther R, Kuechler T, Becker T, Braun F. Spontaneous decision of organ donation in patients signing informed consent for liver transplantation. Transplant Proc. 2013 May;45(4):1305-6. doi: 10.1016/j.transproceed (access: 2013.01.22).

7. Banas B, Bleyer B, Eckert M, Gruber H, Pfirstinger J, Schaller O, Dietl B. [Level of information of students at the University of Regensburg concerning organ donation and transplantation--informed or not informed consent in organ donation?]. Dtsch Med Wochenschr. 2013 Apr; 138(15): 775-80. doi: 10.1055/s-0032-1332960. Epub 2013 Apr 2. (in German).

8. Ismail SY, Luchtenburg AE, Kal-V Gestel JA, Zuidema WC, Weimar W, Busschbach JJ, Massey EK. Modifiable Factors in Access to Living-Donor Kidney Transplantation Among Diverse Populations. Transplantation. 2013 Jun 24. [Epub ahead of print].

9. Georgiadou E, Sounidakis N, Mouloudi E, Giaglis P, Giasnetsova T, Marmanidou K, Gritsi-Gerogianni N. Attitudes and behavior toward organ donation in Greece. Transplant Proc. 2012 Nov;44(9):2698-701. doi: 10.1016/j.transproceed (access:2012.09.17).

10. Jung H. Reluctance to donate organs: a survey among medical students. Transplant Proc. 2013 May;45(4):1303-4. doi: 10.1016/j.transproceed. (access: 2013.02.37).

11. Murray L, Miller A, Dayoub C, Wakefield C, Homewood J. Communication and consent: discussion and organ donation decisions for self and family. Transplant Proc. 2013 Jan-Feb;45(1):10-2. doi: 10.1016/j.transproceed. (access: 2012.10.21).

12. Liu S, Liu C, Cao X, Shang B, Chen A, Liu B.The Difference in the Attitude of Chinese and Japanese College Students Regarding Deceased Organ Donation. Transplant Proc. 2013 May 31. pii: S0041-1345(12)01327-9. doi: 10.1016/j.transproceed. (access: 2012.09.19). [Epub ahead of print]

13. Sperling D, Gurman GM. Factors encouraging and inhibiting organ donation in Israel: the public view and the contribution of legislation and public policy. J Bioeth Inq. 2012 Dec; 9(4): 479-97. doi: 10.1007/ s11673-012-9398-3. Epub 2012 Oct 12.

14. Esezobor CI, Disu E, Oseni SB. Attitude to organ donation among healthcare workers in Nigeria. Clin Transplant. 2012 Nov; 26(6): E612-6. doi: 10.1111/ctr.12032. Epub 2012 Oct 16. 
15. Uskun E, Ozturk M. Attitudes of Islamic religious officials toward organ transplant and donation. Clin Transplant. 2013 Jan-Feb; 27(1): E37-41. doi: 10.1111/ctr.12058. Epub 2012 Dec 30.

16. Barnieh L, Klarenbach S, Gill JS, Caulfield T, Manns B. Attitudes toward strategies to increase organ donation: views of the general public and health professionals. Clin J Am Soc Nephrol. 2012 Dec; 7(12): 1956-63. doi: 10.2215/CJN.04100412. Epub 2012 Sep 27.

17. Afshar R, Sanavi S, Rajabi MR. Attitude and willingness of high school students toward organ donation. Saudi J Kidney Dis Transpl. 2012 Sep; 23(5): 929-33. doi: 10.4103/1319-2442.100863.

18. Ozdag N. The nurses' knowledge, awareness and acceptance of tissueorgan donation. EDTNA ERCA J. 2001; 27(4): 201-6.

19. Sque M, Payne S, Vlachonikolis I. Cadaveric donor transplantation: nurses' attitudes, knowledge and behaviour. Soc Sci Med. 2000; 50(4): 541-52.

20. Molzahn AE. Knowledge and attitudes of critical care nurses regarding organ donation. Can J Cardiovasc Nurs. 1997; 8(2): 13-8.
21. Akgün HS, Bilgin N, Tokalak I, Kut A, Haberal M. Organ donation: a cross-sectional survey of the knowledge and personal views of Turkish health care professionals. Transplant Proc. 2003; 35(4): 1273-5.

22. Jung-Ran Theresa Kim, Murray J Fisher, Doug Elliott. Undergraduate nursing students' knowledge and attitudes towards organ donation in Korea: Implications for education. 2006; 26(6): 465-474.

23. Bener A, El-Shoubaki H, Al-Maslamani Y. Do we need to maximize the knowledge and attitude level of physicians and nurses toward organ donation and transplant? Exp Clin Transplant. 2008; 6(4): 249-53.

24. Tam WW, Suen LK, Chan HY. Knowledge, attitudes and commitment toward organ donation among nursing students in Hong Kong. Transplant Proc. 2012 Jun;44(5):1196-200. doi: 10.1016/j.transproceed. (access: 2012.01.8).

25. Bardell T, Hunter DJ, Kent WD, Jain MK. Do medical students have the knowledge needed to maximize organ donation rates? CanJ Surg. 2003; 46(6): 453-7. 